\title{
Seduções e traições de gênero no Islã: a rainha de Sabá e o corpo feminino circuncidado *
}

\author{
Mariane Venchi ${ }^{* *}$
}

\begin{abstract}
Resumo
Este artigo analisa narrativas árabe-islâmicas que tratam de noções de corporalidade e suas conexões com a prática da circuncisão feminina, mostrando que a relação existente entre circuncisão, sexualidade e poder está posta em um cenário que envolve não apenas um idioma religioso de conversão de quem está dentro (crente) e fora (descrente) e em estados de "poluição", assim como a conversão simbólica entre masculino/feminino subjacente à construção da "comunidade muçulmana" ou califado.
\end{abstract}

Palavras-chave: Literatura Árabe-Islâmica, Alegorias de Gênero e Corporalidades, Circuncisão Feminina, Historiografia Muçulmana.

\footnotetext{
* Recebido para publicação fevereiro de 2008, aceito em maio de 2008. Este artigo é parte de minha dissertação de Mestrado, defendida em 2008 no IFCH/Unicamp, e vinculada ao projeto temático FAPESP "Gênero, Corporalidades", desenvolvido junto ao Núcleo de Estudos de Gênero - Pagu.

** Mestre em Antropologia Social. marive@lexxa.com.br
}

cadernos pagu (30), janeiro-junho de 2008:161-197. 
Seduções e traições de gênero no Islã

Gender Treasons and Seductions in Islam:

The Queen of Sheba and the Circumcised Female Body

\begin{abstract}
This article analises Arab-Muslim narratives dealing with concepts of embodiment in the practice of female circumcision, pointing out that the conection among circumcision, sexuality and power takes place in a setting which involves a religious language of conversion among insiders (believers), outsiders (non-believers) and those in state of "pollution" as well as the simbolic conversion between male/female identities subjacent to the idea of "Islamic community" or caliphate.
\end{abstract}

Key Words: Arab-Muslim Literature, Allegories of Gender and Embodiment, Female Circumcision, Islamic Historiography. 
No society prospers that allows a woman to rule over them. hadith de Maomé ${ }^{1}$

(...) Vou dilacerar o corpo opaco do outro, obrigá-lo, (quer ele responda, quer ele se retire ou se abandone) a entrar no jogo do sentido: vou fazê-lo falar, (...) uma atividade desesperada da palavra: instaurar, a cada ocasião furtiva, o sistema (o paradigma) da pergunta e da resposta (Barthes, 2003:86).

A inspiração para esta reflexão sobre corpo, poder e religião partiu da coleta e análise antropológica de narrativas islâmicas implementadas durante minha pesquisa sobre a circuncisão feminina. Chamou-me particularmente a atenção um conto da tradição historiográfica muçulmana baseado em versos do Alcorão, que descreve em sua linguagem sagrada o encontro de dois chefes-de-estado: a rainha de Sabá e o rei Salomão. Trata-se de uma narrativa, parte histórica, parte literária, marcada por signos de gênero em negociação e rituais de reconhecimento entre duas alteridades, que podem ser pensadas como alegorias para a construção discursiva do corpo feminino e seus respectivos órgãos genitais externos antes e após sua conversão ao Islamismo. A exemplo da crítica de Ella Shohat (2004) sobre a rainha Cleópatra, apropriada por expectativas raciais do imperialismo ocidental, a análise de discursos aqui empreendida gira em torno do debate dos lugares metafóricos do corpo e das lutas e fronteiras de gênero e nacionalismos contemporâneos no processo de construção, seja de fatos, seja de ficções. Na tentativa de resgate e reconstrução do

1 A'hadith são as chamadas tradições do Profeta, isto é, costumes, hábitos, folclore (provérbios, sabedoria popular), que foram coletadas durante a existência de Maomé e compiladas depois de sua morte como um referencial para a conduta ideal do muçulmano. O Profeta teria feito esse comentário quando seu conselheiro Abu Bakr mencionou a rainha de Sabá em sua presença. 
Seduções e traições de gênero no Islã

passado, lemos nas entrelinhas processos que ocultam manobras político-religiosas. Se para Shohat,

ansiedades sobre outros tipos de misturas, sobre a troca de outros fluídos e cores foram projetadas num sangue que nunca deixou de ser vermelho [e se] a despeito de sua natureza quase fictícia, os tropos raciais exercem assim influência real no mundo (Id. ib.:26),

o mesmo pode ser dito sobre feminilidades e masculinidades.

O eixo conceitual desse debate está centrado na relação trabalho/sexualidade/domesticidade, investigada por Anne McClintock $(1995)^{2}$ na Inglaterra vitoriana, que se aplica no caso de corporalidades e relações de gênero no discurso islâmico. A autora mostra como o trabalho doméstico feito por mulheres nas casas abastadas inglesas era invisibilizado, mas cuja manutenção estava, no limite, organizando a sociedade vitoriana, ocultando, por assim dizer, ardis de dominação e desigualdade e expondo contradições deixadas à margem do campo político, campo este que se constitui mediante exclusões e cria sujeitos desautorizados (Butler, 1998). ${ }^{3}$ Tais paradoxos e invisibilizações se manifestam, ainda que nas entrelinhas, na saga da rainha de Sabá islamizada, assim como na construção discursiva da materialidade através de intervenções genitais, muitas vezes, invasivas e dolorosas.

\section{As "inteiras" e as "purificadas":}

sobre a circuncisão feminina e os muçulmanos

Nas disputas retóricas entre religiosos, médicos, acadêmicos e movimentos radicais, as diversas práticas de circuncisão

2 Principalmente os capítulos: "Imperial leather: race, cross-dressing and the cult of domesticity" e "No longer in a future Heaven: nationalism, gender and race".

3 Este texto é minha segunda inspiração conceitual, trata dos fundamentos da teoria do sujeito no campo político enquanto o lugar da "nãorepresentatividade", discussão muito próxima ao trabalho de McClintock. 
masculina $e$ feminina presentes nas três religiões abraâmicas mesclam-se com as leis sagradas, o que suscita entraves para se erradicá-las nas comunidades. ${ }^{4}$ Em círculos muçulmanos onde se pratica a circuncisão feminina, dois termos são usados nas fontes canônicas: khitan al-sunnah, ou al-sunnah, que significa "circuncisão de acordo com a tradição de Maomé", o corte do prepúcio do clitóris, sem a amputação total do mesmo. Alguns especialistas da lei islâmica dizem que o clitóris deve permanecer, outros afirmam que esse nome qualifica a eliminação do clitóris $e$ dos lábios menores, não havendo, assim, consenso em eliminar apenas o capuz, a glande ou todo o órgão ${ }^{5}$, cujo léxico é também utilizado para contrastá-lo à prática da infibulação. ${ }^{6}$ Embora os estudiosos muçulmanos insistam que essas intervenções devam ser implementadas por médicos experientes, grande parte as operações são feitas por parteiras tradicionais (daya) e barbeiros. $\mathrm{Na}$ ausência da menção da circuncisão feminina no Alcorão, recorre-se aos a'hadith para preencher as lacunas sobre costumes, método de exegese aplicado nos casos onde existem supostas ambigüidades.

Apesar de os juristas reservarem pouco espaço de discussão para a circuncisão feminina e masculina, muitos afirmam que essas alterações corporais são parte dos rituais islâmicos, devendo ser feitas para honrar os cônjuges, principalmente o marido. A árabe Um-Habibah indagou ao Profeta se ela poderia continuar

\footnotetext{
4 Ver a extensa monografia publicada sobre o tema (Abu-Sahlieh, 2001).

5 Os pesquisadores da circuncisão fora da exegese islâmica adotam terminologias diferentes de acordo com cada procedimento que descrevem, tentando obedecer ao léxico adotado pelos sujeitos que as praticam. Nesse caso, o nome "sunna", de fato, pode qualificar a extirpação total do clitóris ou excisão.

6 Infibulação: eliminação do clitóris seguida da extirpação dos lábios vaginais, cujos tecidos que restam são costurados, fechando a abertura vaginal e deixando um espaço mínimo para a saída da urina e do fluxo menstrual; pode-se também retirar tecido do interior da vagina. $\mathrm{Na}$ maior parte das fontes por mim consultadas, permanece uma diferenciação básica entre excisão (sunna) $x$ infibulação.
} 
Seduções e traições de gênero no Islã

praticando-a em suas escravas e completou "[eu o farei] a menos que seja proibida e você me ordene que pare de fazê-la". Maomé teria dito: "Sim, é permitido. (...) Mas se cortar, não corte demais" (Abu-Sahlieh, 2001:113). Nawal Al-Saadawi (1991:39) reproduz com exatidão as supostas palavras do Profeta:

If you circumcise, take only a small part and refrain from cutting most of the clitoris off... The woman will have a bright and happy face, and is more welcome to her husband [grifo meu], if her pleasure is complete. ${ }^{7}$

Depois de Maomé, outros juristas mencionaram o tema:

(...) Malik (d.795) said: "Who buys a slave should circumcise her if he wants to enclosure her. But if he intends to sell her, he does not need to circumcise her". This means that the circumcised female slave would be easier to master and keep home (Abu-Sahlieh, 2001:164). ${ }^{8}$

Ibn-Qayyim Al-Jawziyyah [morto em 1351] justifies male and female circumcision for the devil hides himself in the foreskin of the uncircumcised man and in the vagina of the uncircumcised woman, as well as in the hairs of the pubis and under the nails. (...) Circumcision has consequences on prayer, pilgrimage, testimony, marriage, slaughtering of animals and burial in a Muslim cemetery (Id. ib:123). ${ }^{9}$

7 "Se você circuncidar, retire apenas uma pequena parte e refreie-se de remover todo o clitóris. A mulher terá uma compleição mais brilhante e alegre, e isso é bem-vindo para o marido, se o seu prazer for completo".

8 Malik (morto em 795) disse: "Aquele que compra uma escrava deve circuncidá-la se desejar enclausurá-la. Se desejar vendê-la, ele não precisa circuncidá-la." Isso significa que a escrava mulher circuncidada deveria ser mais fácil de ser mantida em casa.

9 Ibn-Qayyim Al-Jawziyyah justifica as circuncisões masculina e feminina pelo fato de o diabo se esconder no prepúcio do homem incircunciso e na vagina da mulher incircuncisa, assim como nos pêlos da púbis e embaixo das unhas. A circuncisão tem conseqüências na oração, peregrinação, testemunho, casamento, degola de animais e enterro em cemitérios muçulmanos. 
Mariane Venchi

The order to circumcise women has two interests: it reduces a woman's excessive concupiscence so that she does not fall into forbidden habits [por exemplo, adultério ou masturbação]. And, it contributes to prolong sexual pleasure leading to orgasm that bonds the two spouses to complete mutual chastity (Al-Sukkari apud Abu-Sahlieh, 2001:165). ${ }^{10}$

Al-Ghawwabi wonders in this respect how a man can lie down with "a woman who has an erect organ (the clitoris) as his".

Men in our countries are often 10, 15, or even 20 years older than their wife. What to think when the man reaches 50 years or more and a reduction of his vitality happens whereas the woman is thirty years old, or even less, having all her sensitive organs intact? How can he preserve his health facing a woman in full youth, very sensual, whereas his sexual impetus cooled? What will be then the result of it? Here the man feels obliged to resort to hashish. But if the woman is half circumcised, her sexual impetus becomes moderate and the man is then equal with the woman (AbuSahlieh, 2001:171). ${ }^{11}$

Na concepção dos juristas, práticas (hetero)sexuais não têm livre curso fora de certos imperativos permitidos, e desvendar suas regras implica também revelar códigos de etnicidade e de

${ }^{10}$ A ordem para circuncidar mulheres tem dois interesses: reduz a concupiscência excessiva da mulher de forma que ela não se remeta a hábitos proibidos. $\mathrm{E}$ contribui para prolongar o prazer sexual que leva ao orgasmo, unindo ambos os cônjuges em completa castidade mútua.

${ }^{11}$ Al-Ghawwabi pondera a esse respeito como pode ser possível um homem se deitar com uma "mulher que tem um órgão ereto (o clitóris) como o dele". Em nossos países, homens são frequentemente 10, 15 ou mesmo 20 anos mais velhos que suas esposas. O que pensar quando o homem atinge a idade de 50 anos ou mais seguida de uma redução de vitalidade, enquanto a mulher tem 30 anos, ou ainda menos, tendo todos os seus órgãos sensíveis intactos ? Como ele pode preservar sua saúde encarando uma mulher jovem, muito sensual, enquanto seu ímpeto sexual está esfriando? Qual será o resultado disso? Aqui o homem se sente obrigado a recorrer a haxixe. Mas se a mulher está circuncidada, seu ímpeto sexual se torna moderado e o homem é então igual à mulher. 
Seduções e traições de gênero no Islã

status social e econômico, como a relação entre pessoas "livres" $e$ "escravas" $e$ os marcadores de geração. Em sociedades muçulmanas, o grau de segregação de sexo e a reclusão das mulheres variam dependendo da idade e do status marital e a reclusão varia conforme a idade das mulheres. Na infância e na velhice, as diferenças de gênero tendem a ser atenuadas e são acirradas no período fértil da mulher, que corresponde mais ou menos aos anos de casamento. As diferenças de gênero, assim, são ritualizadas e acionadas nas seguintes ocasióes: nascimento, circuncisão, casamento e morte.

Nessas fontes, observamos a relação entre a instituição do concubinato/escravidão e o tema da circuncisão feminina. Existe um conceito muito específico referente ao concubinato no Islamismo, as chamadas "jawari", escravas mulheres ou concubinas (Mernissi, 2003:53). "Concubina", na definição moderna, é uma mulher "amasiada", que coabita com um homem consensualmente sem estar casada. No Oriente Médio da Antiguidade e Idade Média, o concubinato não era baseado na escolha da mulher, porque poderia ser dissolvido sem seu consentimento e tinha uma origem opressiva vinda da captura de prisioneiros de guerra e do status de escravo. Em geral, a concubina era destinada aos "prazeres carnais" de seus captores e inserida nas cortes de reis e sultões, instituição que durou mais ou menos até a época Otomana no século XIX. ${ }^{12}$

${ }^{12}$ Para um percurso histórico dos impérios muçulmanos, ver Hourani (2005). A origem e a construção do status de escravo, segundo parâmetros de raça, gênero e língua no Islamismo, são complexas e mereceriam uma digressão histórica que extrapola o espaço conceitual deste artigo. No entanto, é preciso citar aqui a mudança do público e do privado após o triunfo do Islamismo em Meca, a morte de Maomé e o poder exercido pelos califas sucessores. Os sultões desejavam ter dançarinas e outras concubinas, criando dependências separadas que não existiam anteriormente nas casas árabes. A mesquita, inicialmente um centro comunitário de debates políticos, vida econômica, socialização e local de culto, passou a ser freqüentada apenas para as orações, dando lugar ao palácio como centro governamental. O califa separou suas esposas oficiais e filhos em aposentos, fragmentando e segregando a esfera doméstica. Assim, “(...) vários 
Mariane Venchi

A prática da circuncisão é certamente um marcador de status e de papéis na esfera privada das casas árabes ou do palácio do sultão e seus cortesãos. Quando comprada, de que forma essa "escrava inteira" seria encaixada na escala de papéis da vida doméstica de classes mais abastadas? Quais as vantagens e desvantagens implícitas à condição de conversão corporal no delicado equilíbrio das relações interpessoais de um lar muçulmano? ${ }^{13}$

Um bom casamento, às vezes, implica conflitos, como a diferença de idade, o temor da perda de potência de um marido mais velho, os "vícios" (uso de haxixe, masturbação, etc.) causados pelo malogro na vida sexual, prejudicando a comunidade com consequente "falha matrimonial"; o divórcio, prática que Maomé desencorajava. Para evitar caos social, as esposas deveriam tomar certas medidas: não se masturbar $e$ exacerbar secreções vaginais; a circuncisão traria vantagens, uma vez que eliminaria a prática, impedindo a excitação "excessiva" dos lábios vaginais, uma visão abjeta e que compromete a potência do esposo, segundo dizem as fontes islâmicas consultadas.

dos escravos apresentavam excelente nível cultural, possuíam capacitação profissional, dominavam técnicas de instrumentação e de composição musical, escreviam poesia, cantavam à perfeição. As prisioneiras mais diferenciadas eram destinadas ao serviço de autoridades governamentais e, devido aos seus dotes físicos e intelectuais, conquistavam os corações de sultões e califas, tornando-se suas favoritas e conselheiras" (ver Gomes, 2000:187).

${ }^{13}$ Para responder essas perguntas, obviamente, precisaríamos de uma pesquisa de campo ou de uma etnografia das fontes históricas de diferentes países e épocas, mas essas indagações permanecem importantes para reflexão porque colocam em diálogo concepções de conversão religiosa/social e corporalidade. Abu-Sahlieh menciona a conversão de cristãos durante a guerra na Bósnia, quando muçulmanos infligiam circuncisões forçadas em seus prisioneiros homens após serem obrigados a proferir a fé muçulmana "Ashhadu an la iláh illa Allah; Ashhadu anna Muhammadan raçul Allah" [Testemunho que não há senão Deus e Muhammad é o mensageiro de Deus]. 
Seduções e traições de gênero no Islã

Uma referência importante para os estudos de gênero $e$ circuncisão feminina no contexto árabe-muçulmano é a etnografia interpretativista de Janice Boddy publicada em 1989, Wombs and Alien Spirits - women, men and the Zar cult in Northern Sudan. A partir de pesquisa de campo na aldeia hofriyati, no Sudão árabe em 1976 e 1977, Boddy analisa a possessão espiritual do ponto de vista da experiência das mulheres, ainda que a perspectiva masculina seja o paradigma hegemônico no qual estão inseridas. A circuncisão não é seu tema principal, mas é fundamental para compreender as práticas sociais dos hofriyati inscritas no corpo das mulheres, socializado conforme o entendimento dos aldeões sobre os vivos e os mortos, dado a partir de um universo compartilhado e no modo como este opera segundo a cosmologia islâmica.

Na construção do corpo feminino, cuja ênfase recai em seu potencial reprodutivo, Boddy postula que a moralidade dos úteros está dada pelas relações de parentesco designadas pelos clãs. Orifícios, aberturas, são vias de acesso para alianças, que devem ser controlados simbolicamente em uniões endogâmicas, para as quais existe previamente uma série de obrigações morais. Na relação simbólica sangue/fertilidade, o sangue é considerado a fonte da fecundidade feminina, por isso a preocupação em prevenir sua perda, contaminação e apropriação indevida por parte de jinni ${ }^{14}$, e assim o útero é fechado, encerrado com a infibulação. A fertilidade da mulher depende da quantidade de sangue que carrega dentro dela e está também associada à idéia do par dor/calor. É a mulher quem precisa ter calor suficiente no útero ou gerá-lo ritualmente para transformar a semente do

14 "Jinni", às vezes grafado como "djinn", traduzido pelos orientalistas como "gênios", são entidades e espíritos associados às profundezas da terra. Segundo o orientalista e cronista britânico Sir Richard Francis Burton, jinni vem da mesma raiz de junnun e majnun: loucura, louco. Alguns deles são convertidos ao Islã, outros são heréticos e ateus. O chefe de todos eles seria Iblis (Satã) chamado de Azazel, o Príncipe das Trevas, também conhecido como Abu-Jaria, anjo da morte que conduzia as almas ao Julgamento. 
marido em uma criança masculina. O calor é um requerimento, um pré-requisito para mulheres, não necessariamente uma característica associada ao feminino. É necessário experimentar calor, trauma e dor ao se depilar, como a infibulação, chamada localmente de "harr", atos femininos de purificação, que preparam a mulher inteira (não-circuncidada) para as cerimônias nupciais, a vida sexual no casamento. Em suma, implica em sua conversão em uma pessoa feminina completa na passagem definitiva para a "maioridade social" com o casamento. ${ }^{15} \mathrm{Em}$ termos conceituais, haveria uma descontinuidade entre sexualidade feminina - fertilidade inapropriada ou "inadequada", causa de desordem ou ruptura na ordem muçulmana - e fertilidade feminina - sexualidade "domesticada" após a circuncisão e o casamento.

Além disso, Boddy reafirma a importância simbólica da vida diária que requer aberturas: portas, bocas, vaginas, olhos, ouvidos e, por fim, o casamento, já que orifícios simbolizam possibilidades de contato. À semelhança desse argumento, Mary Douglas (1976) já situara os chamados simbolismos corporais como portadores de noções perturbadoras, que elegem os "orifícios" (no caso, a vulva) como o locus por excelência de tabu e desordem, pois seriam pontos específicos da anatomia humana que simbolizariam a ultrapassagem dos limites corporais, em uma analogia com a entrada e saída (circulação) de grupos sociais. A autora aponta para o interesse de muitas sociedades nas entradas e saídas corporais da mulher, associando a questão à "poluição sexual", cujo domínio estruturante de noções dicotômicas de pureza e perigo expressariam, em termos inconscientes, a simetria $e$ a hierarquia, ou a estrutura social do grupo. Aqui, o potencial

${ }^{15}$ Kennedy (1970:183) discute como o ritual da excisão (nome que o autor adota para qualificar a infibulação) se relaciona com a sociedade Núbia - na fronteira entre Egito e Sudão - de forma a proporcionar solidariedade e um senso de identidade, tornando essas operações genitais e o casamento partes de um "cerimonial único e complexo com múltiplos significados", extrapolando a função de "rito de passagem". 
Seduções e traições de gênero no Islã

de fertilidade das mulheres é fundamental à Ummah (comunidade islâmica) ${ }^{16}$, sendo simultaneamente uma instância ambígua e perigosa, porque não é previsível nem controlável.

Uma discussão sobre direitos das mulheres em sociedades muçulmanas, seus corpos e vontades individuais, envolve os conceitos de autonomia e técnicas de escrutínio do corpo, determinados por marcadores de gênero e geração, que, por sua vez, se encontram situados em contextos de conversão religiosa, um tema recorrente em narrativas islamizadas que tratam de sexualidade, etnicidade e tecnologias de violência.

\section{A concha torta e a sedução interrompida: as charadas de Sabá e os serões de Sherazade}

Em sua obra ainda não traduzida no Brasil, The Forgotten Queens of Islam (2003), Fatima Mernissi ${ }^{17}$ desvela o suposto apagamento, por parte de historiadores e/ou teólogos muçulmanos modernos, sobre o desempenho público de algumas mulheres palacianas das dinastias dos Impérios muçulmanos, criticando uma historiografia ainda presa aos grilhões de um dever sagrado que constrói a memória coletiva islâmica de forma misógina. A autora propõe um experimento historiográfico a partir do qual me inspiro aqui; a saber, uma tentativa de

${ }^{16}$ A "Ummah" demarca uma conexão moral cujo cimento seria o cumprimento da lei divina em busca da felicidade não apenas na Terra, mas na vida após a morte, regida pelas leis islâmicas extraídas de princípios do Alcorão e das tradições do Profeta (cf. Hourani, 2005).

${ }^{17}$ Mernissi estudou ciência política na Sorbonne e concluiu o doutorado pela Universidade de Brandeis, atualmente, é professora de sociologia da Universidade Mohammed V em Rabat. Escritora e feminista, suas preocupações giram em torno do papel e dos direitos das mulheres no Islã, tendo um de seus livros traduzidos no Brasil, uma autobiografia Sonhos de transgressão - minha vida de menina num harém (1996). Suas obras estão contextualizadas política e historicamente na revisão das leis islâmicas no Marrocos que vem tomando forma nas últimas décadas desde 1957 e com mudanças significativas a partir de 2004 - a reforma do Código Civil, sobretudo as leis da família que governam os muçulmanos. 
reescrever fragmentos da história islâmica para além dos discursos oficiais de pesquisadores medievais e contemporâneos de sua tradição, afirmando a necessidade de uma narrativa que aponte as resistências, as tensões e as rejeições em torno da idéia de que existem muitas verdades no tocante à historiografia árabe, um debate acadêmico ainda embrionário no mundo islâmico.

Selecionando a trajetória pessoal e política de algumas rainhas, princesas e cortesãs, Mernissi mostra o que é ou não permitido às mulheres no espaço público, apontando a relação entre política/religião/universo público $x$ privado/administração, que pressuporia a exclusão das mulheres, pois o poder é divino $e$ masculino. Não existe forma feminina para as palavras imame ${ }^{18} e$ 'al-khalifatu' (o califa), as duas palavras que envolvem poder na língua árabe, idioma no qual o Alcorão foi revelado. Pressupõe-se que nenhuma mulher tenha legitimidade para ser a califa, a líder espiritual suprema da Ummah, tampouco para assumir outras funções políticas que detêm o poder da retórica sagrada. Por outro lado, existe o feminino de rei (malik - malika), um cargo profano, ou título de nobreza. Quando na mão de mulheres, o poder só teria sido dado a partir do consentimento dos homens, à exceção da chefe de Estado Bilqis, conhecida popularmente como a "Rainha de Sabá", anterior ao Islamismo. Dessa forma,

(...) as soon as a woman came close to the throne, a group whose interests she threatened appeared on the scene and challenged her in the name of the spiritual, the name of the shari'a. ${ }^{19}$ This was true even when she operated in an

${ }^{18}$ Condutor das orações nas mesquitas, que lidera as preces públicas e faz sermões nas sextas-feiras; tem influência política forte nas comunidades. $\mathrm{O}$ imame é uma função, não um título acadêmico, ou seja, ele não é necessariamente um especialista em teologia.

${ }^{19}$ Shari'ah: a vontade de Alá para com o indivíduo perante o mundo e os outros muçulmanos, expressa conforme o Alcorão e a sunna do Profeta; as leis sagradas do Islã. Não é um código de lei fechado e sistematizado, mas uma série de procedimentos, isto é, formas que a lei estabelece para se tratarem de causas em juízo. 
Seduções e traições de gênero no Islã

obviously unstable revolutionary context. (...) Women, then, have reigned over the lands of Islam and directed their governments but always in violation of the spiritual principles that underpin and legitimize political authority. Why? We know that gender and politics are so closely tied that it is absolutely impossible to separate them, especially in cultures where man/woman subordination incarnates and symbolizes authority.(...) [grifo meu] Any infiltration of women into Muslim political arena is seen as disruptive (Id. ib.:30-31)..$^{20}$

Se a sexualidade feminina é uma instância de perigo $e$ subversão, assim também é a presença feminina em um cargo público em um universo onde política, sexo e gênero se encontram irremediavelmente atrelados. Bilqis é mais conhecida como a "Rainha de Sabá", personagem bíblica que visitou a Corte do rei Salomão. O teórico literário Jacob Lassner (2002) recupera narrativas da visita da rainha, interpretada como uma missão diplomática para garantir rotas comerciais, segundo a hipótese moderna da visita, registrada pelos cronistas bíblicos e reformulada posteriormente por escritores judeus e muçulmanos para acomodarem valores contemporâneos e preocupações sociais redefinidas. Nas fontes medievais, a narrativa assumiu um tom alegórico, representando a perigosa tentativa de transgressão às regras sociais e papéis de gênero, na qual a hegemonia masculina teria sido testada por uma mulher extraordinária. Muçulmanos e judeus teriam reescrito a história retratando-a

20 "Assim que uma mulher se aproximava do trono, os grupos, cujos interesses ela ameaçava, entravam em cena e a desafiavam em nome do espiritual, em nome da shari'a. Isso valia mesmo quando ela operava em um contexto revolucionário obviamente instável. (...) As mulheres, então, reinaram nas terras do Islã e dirigiram seus governos sempre violando os princípios espirituais que corroboram e legitimam a autoridade política. Por quê? Sabemos que gênero e política estão intimamente ligados, de forma que é impossível separá-los, especialmente em culturas nas quais a subordinação homem/mulher encarna $e$ simboliza a autoridade. Qualquer infiltração de mulheres na arena política muçulmana é vista como demolidora". 
como uma "força demoníaca" (Id. ib.:1) apta a dissolver as barreiras assimétricas de poder entre masculino e feminino, isto é, anulando posições sociais/sexuais naturalizadas.

$\mathrm{Em}$ se tratando de rainhas do Oriente Médio na antiguidade, devemos considerar o trabalho dos cronistas a partir do filtro de sua percepção sobre as verdades de sua época. Como a rainha de Sabá, muitas soberanas foram alvo de atenção, como as rainhas Zenóbia, Cleópatra, Irene, Jezebel, Esther, algumas construídas como estrangeiras, idólatras e, portanto, de sexualidade suspeita e temida. ${ }^{21}$ Segundo Lassner (2002:ix), a narrativa da Rainha de Sabá aponta para um "projeto de relações intercomunais", duas fés conectadas que competem por versões de um passado legítimo. Nas fontes judaicas, está relacionada com o demônio Lilith ${ }^{22}$ e, em interpretações modernas, torna-se uma heroína compatível com os padrões emancipatórios femininos do século XX e XXI, por sua sagacidade em lidar com os homens, seu desejo por independência política e sua autonomia em tomar decisões sobre a própria vida.

A historicidade da rainha de Sabá foi, assim, alvo de diversos discursos que lidavam com a porosidade de fronteiras geográficas entre povos na Antiguidade e Idade Média; várias versões antigas e modernas competem como legítimas, embora não se tenha evidências arqueológicas de sua existência no décimo século antes de Cristo (mais ou menos 900AC). O primeiro historiador israelita, Flavius Josephus ${ }^{23}$, identificou a

${ }^{21}$ Essas rainhas são alvos de pesquisa acadêmica, sobretudo na área de estudos bíblicos e arqueologia do Oriente Médio (ver Beach, 2005).

22 "Lilith" vem da raiz suméria LIL, cuja palavra "Lulu" significa "libertinagem" (Sicuteri, 1998). Lilith seria um demônio das trevas que incita à volúpia, "a paixão turva da sexualidade desenfreada que pode insidiar e submeter o homem" (Id. ib.:42).

${ }^{23}$ Nascido em $37 \mathrm{AC}$, renomado diplomata e historiador da Corte romana durante o reinado de Vespasiano. Ele teria presenciado e registrado a destruição do templo de Jerusalém e do Segundo Templo em 70 AC, ocupando-se do estudo sobre a origem das guerras. 
Seduções e traições de gênero no Islã

visitante da corte de Salomão como uma soberana do Egito ou da Etiópia. Os etíopes recuperam-na como a soberana fundadora de sua nação a partir de seu filho com Salomão, Menelik I, o primeiro imperador etíope. Existem também várias versões sobre ser a esposa ou filha de um faraó do Egito, ou uma monarca sabéia do sul da Arábia ou de algum reino próximo a Jerusalém. ${ }^{24}$ A personagem também foi arabizada e a narrativa de sua visita a Salomão ("Suleyman", convertido em muçulmano) aparece no Alcorão. Segundo Mernissi, ela seria uma rainha iemenita pré-islâmica mencionada no Livro Sagrado dos muçulmanos, tendo importância histórica e valor espiritual, já que renuncia ao politeísmo de culto ao sol, primeiro curvando-se à sabedoria do rei Salomão e depois à Alá. Chama a atenção o fato de essa ser a única rainha que emerge do período préislâmico; na poesia árabe, Bilqis - como é conhecida em árabe é evocada como uma presença feminina que fascina e encanta, a despeito de a história contemporânea ter-lhe atribuído um caráter mais fictício, o que a autora considera uma tentativa de apagar o poder de uma soberana que teria existido, cuja importância é corroborada pelo próprio Alcorão. ${ }^{25}$

24"Rainha de Sabá" vem também do latim reino sabo, "rainha sábia", sendo associada no Gnosticismo com Maria, a Profetisa ou a Virgem Negra, a maior mulher alquimista, rainha e concubina de Cristo. A figura dessa rainha representada como sacerdotisa ou luxúria também foi a favorita de escritores ocidentais como Anatole France, Victor Hugo (que a chamava de Lilith), Flaubert e Gérard de Nerval (ver Begg, 1996).

${ }^{25}$ Mernissi (2003:116) revela: "A colleague of mine, a historian who specializes in the Middle Ages, whom I consulted at the beginning of my research for information on this subject, was very sceptical. Arab women, heads of state? Are you not mistaken about the area? When I recited to him the form used when the khutba [sermão recitado na mesquita em honra ao califa] was proclaimed in 'Arwas's name [uma rainha], he asked me with disconcerting conviction: 'Didn't you read that story in the Arabian Nights?' Still more surprising is that this amnesia affects even Western historians, who seemingly should not be all threatened by the Arab woman/power connection" [Um colega meu, um historiador especializado na Idade Média, que consultei no começo de minha pesquisa para me informar sobre esse assunto, foi muito cético. Mulheres árabes, 
Lassner estuda dois tipos de versões árabe-islâmicas: aquela do Livro Sagrado e algumas narrativas de juristas medievais que interpretam os cânones dos versos nos quais ela aparece ao lado do rei. As versões medievais são mais detalhadas porque constroem interpretações e ficções a partir da versão alcorânica. Nas versões escritas do comentador Al-Thalabi ${ }^{26}$, há uma complexa reconstrução narrativa da relação entre Bilqis $e$ Suleyman, a começar pela genealogia da rainha. Seu pai teria sido al-Bashrakh, um rei poderoso, governador de todos os reinos sabeus do lêmen, membro de linhagem considerada superior às dinastias de outras províncias, recusando-se a casar com os clãs de seu povo. Diz a lenda que ele casou-se com a filha do rei dos jinni, Rayhanah bint Al-Shukr, e teve uma única filha, Bal'amah ou Bilqis.

Com a morte de al-Bashrakh, Bilqis herda o trono, mas uma dissidência palaciana recusa-se a aceitá-la como rainha, por ser uma soberana mulher e descender de uma linhagem "perigosa". Ela é preterida por um jovem dos círculos palacianos que se revela um rei tirânico. Ao ocupar o trono, ele a exila, exigindo a posse das mulheres de seus subalternos e matando uma a uma. O reino se divide. Ardilosa, Bilqis tem uma estratégia para destronar o tirano: manda uma carta oferecendo sua própria mão em casamento. Surpreso, ele diz ter pensado no assunto, mas mostrara-se recalcitrante em propor-lhe a união, sendo ela de origem nobre e filha de uma jinni. Ela aceita oficialmente o pedido de casamento, dizendo aos diplomatas "Eu amava esse rapaz. Não respondi a ele antes porque preferia não me casar, mas agora dou meu consentimento a ele." Na noite de núpcias, embebeda o noivo e decepa sua cabeça, pendurando-a no portão

chefes de Estado? Você não viu isso nas Mil e Uma Noites? Ainda mais surpreendente foi saber que essa amnésia afetou até mesmo os historiadores ocidentais que, aparentemente, não deveriam ser ameaçados pela conexão árabe entre mulher e poder].

${ }^{26}$ Ibrahim Al-Thalabi (morto em 1036 DC), jurista considerado pelos sunitas um importante estudioso do Alcorão. 
Seduções e traições de gênero no Islã

principal do palácio, com a qual os súditos se deparam, assombrados, na manhã seguinte. Ela recupera seu título de rainha legítima por direito de sucessão e ocupa o poder, cujo status é simbolizado por um suntuoso trono e descrições extravagantes de seu palácio lendário. Só a sala do trono possuía sete antecâmaras, cada qual era protegida por um portão trancado.

O Alcorão apresenta essa personagem na sura 27, a "formiga" 27 , após a menção aos profetas David e Moisés e a exaltação de Suleyman a Deus, que lhe revelou a "linguagem dos pássaros". ${ }^{28}$ Ao redor de Salomão reuniram-se as hostes de jinni, homens e pássaros (criaturas do ar), em batalha contra as formigas no vale (criaturas da terra). Suleyman roga ao Senhor para trazer-lhe a vitória. Ao inspecionar suas tropas, falta um pássaro, a poupa ${ }^{29}$, que surge em seguida e justifica sua ausência dizendo que viera do reino de Sabá com novidades:

${ }^{27}$ The Noble Qur'an - English Translation of the meanings and Commentary. Madinah, King Fahd Complex For the Printing of the Holy Qur'an, 2005. A edição consultada aqui é a versão original do Alcorão com a tradução em inglês e comentários explicativos.

${ }^{28} \mathrm{Na}$ tradição islâmica, os pássaros simbolizam os anjos, criaturas mediadoras entre o céu e a terra que, com seus vôos em diferentes planos, conectam diferentes dimensões da realidade. Podem ser interpretados como o conector universal do espírito. Aqui, revelar a "linguagem dos pássaros" é reviver o mistério da Enunciação Original. Literato, profeta e poeta, Salomão tinha a sabedoria para desvendar tal linguagem que se vale das qualidades intrínsecas das coisas para simbolizar ontologias que as transcendem, como os místicos que dissertam sobre os atributos divinos e a ascensão às esferas superiores. Os princípios da iniciação ao misticismo islâmico se encontram na obra persa clássica do mestre sufi Farid Ud-Din Attar (A Linguagem dos Pássaros, 1991).

${ }^{29}$ No segundo capítulo da obra supracitada, Attar dedica uma narrativa à poupa, que discursa na assembléia dos pássaros: "Prezados pássaros, sou um dentre aqueles engajados na milícia divina, sou a mensageira do mundo invisível. Conheço Deus e os segredos da criação. Quando, como eu, se tem inscrito no bico o nome de Deus ["Não há outro deus senão Deus", a primeira parte da profissão da fé muçulmana], necessariamente deve-se ter conhecimento de muitos segredos. Encontrei-me com Salomão e sou o primeiro de seus seguidores. (...) Eu levava suas cartas e era seu confidente: o pássaro que é 
Mariane Venchi

I found a woman rulling over them: she has been given all things that could be possessed by any ruler of the world, and she has a great throne $(27: 23) .{ }^{30}$ I found her and her people worshipping the sun instead of Allah, and Shaitan [o demônio] has made their deeds far-seeming to them and has barred them from Allah's way: so they have no guidance (27:24). ${ }^{31}$

A poupa entrega uma carta de Suleyman à rainha, intimando-a a converter-se ao Islã. Encorajada por seus conselheiros a tomar sozinha sua decisão, a rainha decide mandar-lhe presentes. Segue uma sequência de versos truncados de difícil compreensão, que Lassner interpreta como uma rejeição dos presentes por parte do rei, fazendo a comitiva voltar com uma segunda mensagem de conversão forçada no caso de sua recusa em aceitar Alá: a invasão militar de seu reino. Enquanto isso, Suleyman planeja roubar literalmente o trono de Bilqis, pedindo para um dos jinni para trazê-lo até si "em um piscar de olhos" $e$ pede ao jinni para que camufle o trono de forma a testá-la. Se ela reconhecer o trono, ela tem de fato sabedoria.

Ao chegar em Jerusalém, ele lhe indaga: "É este seu trono?" Bilqis não responde sim ou não, apenas replica de forma evasiva: "É como se fosse o mesmo" (27:29). Em outra tentativa de testá-la, Suleyman usa de um subterfúgio com a ajuda de um jinni: pede para a entidade criar uma superfície espelhada imitando a água entre seu trono e o caminho que o separa de Bilqis, em seguida a faz entrar na sala e pede para que se aproxime dele. Pensando ser um lago, ela ergue o manto e o vestido e descobre as pernas, anunciando: "My Lord, I have

querido pelo profeta Salomão merece ter uma coroa em sua cabeça" (Id. id:4344)].

${ }^{30}$ Encontrei uma mulher governando-os: a ela foi dado tudo que poderia possuir qualquer líder do mundo, e ela tem um grande trono.

${ }^{31}$ Encontrei ela e seu povo adorando o sol em vez de Alá e Shaitan fez seus atos atraentes a eles e os bloqueou do caminho de Alá: assim, eles não têm direção. 
Seduções e traições de gênero no Islã

wronged myself, and I submit to Allah, the Lord of the Alamin" $(27: 44){ }^{32}$ Aqui é interrompida a narrativa sagrada, sem mais detalhes descritivos ou explicativos.

$\mathrm{Na}$ versão reconstruída por Thalabi, ao saber da rainha politeísta, Suleyman manda sua carta selada e a borrifa com perfume de almíscar. A poupa deposita a carta em seu colo enquanto ela dorme. Bilqis, que era letrada, quando pegou a carta estremeceu ao ver seu emblema no selo, sabendo ser de um grande rei. Então, curvou-se, admitindo que todo rei que usa como mensageiro um pássaro é um grande e nobre soberano. ${ }^{33}$ O presente que manda é uma legião de escravos, servas e cortesãos, ouro, especiarias e enigmas para testar a inteligência de Suleyman.

Ela veste os escravos homens como mulheres e vice-versa. Coloca as meninas travestidas sobre corcéis $e$ os homens travestidos sobre pôneis e pede ao mensageiro que lhe entregue uma caixa de jóias, colocando ali dentro uma pérola perfeita $e$ caríssima e uma concha torta. Então ela lança-lhe um enigma:

Se você for um profeta, distinga entre as servas $e$ os cortesãos, diga-nos o que há na caixa antes de abri-la. [e se adivinhasse, o mensageiro lhe diria] Perfure uniformemente a pérola lisa e alinhe a concha deformada.

Antes de a comitiva partir, Bilqis recomenda aos jovens que falem $e$ ajam afeminadamente $e$ às jovens que falem grosso. Depois diz ao chefe da comitiva, Al-Mundhir Amr: "Olhe diretamente para o homem e, se ele mirá-lo com raiva ele não é digno, mas se olhá-lo com bondade, então ele é um profeta e emissário de Deus". A

${ }^{32}$ Meu Senhor, eu me enganei. E me submeto a Alá, o Senhor dos Alamin.

${ }^{33}$ Diz-se que o selo de Salomão é a única tranca que mantém os jinni retidos em garrafas, lâmpadas, cavernas e baús, a única forma de serem aprisionados por humanos. A consternação submissa de Bilqis aqui expõe sua fragilidade diante da autoridade do rei, justamente por ser filha de uma jinni. 
Mariane Venchi

poupa, que estava escondida ouvindo, voou de volta ao seu mestre e informou-o sobre o ardil da rainha.

O anjo Gabriel coloca-se ao lado de Suleyman na recepção à comitiva e revela-lhe o que há na caixa. O rei acerta o enigma do porta-jóias e realiza a tarefa proposta pela rainha. Ele pede ajuda às minhocas da terra para colocarem a linha na pérola; elas tiram um pedaço de seu cabelo, fazendo-o de linha, perfurando-a com a boca. Ele consegue distinguir os jovens das moças fazendoos lavar-se e observando sua hexis corporal. Enquanto as moças transferem a água de uma mão para outra, vertendo-a suavemente e se lavam a partir da parte de dentro do antebraço, os jovens pegam a água e "jogam-na" simplesmente na parte de cima, espirrando grosseiramente para os lados.

Ao saber que Suleyman triunfara nas provas, Bilqis resolve visitá-lo pessoalmente. "Por Deus! Esse não é um rei! Somos impotentes para lidar com ele!". Em sua ausência, ela ordena aos vizires para que tranquem seu trono no mais distante e protegido de seus palácios. Enquanto isso parte com sua comitiva, composta por 12 mil governadores dos reinos do lêmen, cada um dos quais protegidos por 100 mil guerreiros. Enquanto a rainha não chega, Suleyman ordena a um dos jinni que lhe traga o trono de Bilqis, aproveitando sua ausência do palácio. O jinni o obedece, mas temendo que seu amo a desposasse resolve então difamá-la, dizendo que a rainha possui pernas peludas e pés iguais aos cascos de uma mula. Suleyman ainda prefere tirar suas próprias conclusões e faz a rainha passar pelo teste do lago na sala do trono.

Ao erguer a saia, o rei vê que tem lindos pés, que nada se parecem com cascos de mula, mas seus tornozelos eram de fato hirsutos. ${ }^{34}$ Ele lhe avisa que não há água, somente uma superfície

${ }^{34}$ Há semelhanças com outras passagens míticas. Na linguagem etíope, Makeda significa "a ardente, flamejante", que a conecta com o símbolo do cometa no céu, a estrela que percorre o firmamento, que em grego significa "hirsuto". Nas narrativas eritréicas e etíopes, Sabá era filha de um tigre conhecido como Eteye Azeb ("rainha do sul") e foi amarrada a uma árvore por ter ofendido um dragão. 
Seduções e traições de gênero no Islã

espelhada, e ela baixa a saia, poupando-lhe da visão dos pêlos inconvenientes. Bilqis senta-se ao seu lado e lhe propõe outra charada: "Traga-me água que se pode beber, mas não se encontra nem no solo e nem no céu". Os demônios sussurram em seu ouvido: "Simples! Ordene aos cavalos que corram e então encha os vasos com seu suor". O profeta responde e passa no teste. Bilqis replica: "Conte-me agora sobre o seu Senhor!"

Incapaz de responder sobre algo irrespondível que é a essência divina, Suleyman tem um colapso e cai no chão, inerte. $\mathrm{O}$ anjo Gabriel vem em seu socorro e o instrui para retomar a consciência e continuar a falar como se nada houvesse acontecido. "Sobre o quê mesmo você falava?", pergunta ele à rainha. "Sobre a água que não existe no céu nem na terra..." "E sobre o que mais você perguntou?" "Mais nada...", responde ela. Deus apaga o passado e o protege de ter de responder à pergunta mais constrangedora de todas. Suleyman, então, roga-lhe que se converta ao Islã e ela cede.

Eles se casam ao final? As versões dos literatos muçulmanos divergem. Uma delas diz que uma vez muçulmana, Suleyman assim o desejou, mas ficou enojado com seus pêlos nas pernas. Ele perguntou aos conselheiros como se poderia remover os pêlos, $e$ foi sugerido que se usasse uma navalha. Bilqis protestou, alegando que "nunca tinha sido tocada por uma lâmina" - alusão à sua suposta condição de "virgem" - e o rei temeu que ela se cortasse ao usá-la pela primeira vez. Pressionados, os demônios revelaram que lhe preparariam um banho com uma fórmula depilatória para arrancá-los. Essa é a lenda da primeira depilação feita especialmente para uma mulher. Outras versões dizem que uma vez casados, Suleyman permitiu que ela voltasse ao seu reino e permanecesse soberana, viajando sempre para lá e visitando-a uma vez por mês por três dias. Outras versões dizem que ele a

Despertos por suas lágrimas, sete santos que descansavam sob a árvore a resgataram e mataram o dragão. Porém, quando o sangue do monstro respingou em sua perna, seus pés se transformaram em cascos de mula. Ela então procurou Salomão para ser curada (cf. Begg, 1996). 
Mariane Venchi

instruiu a desposar um homem de seu próprio reino. Protestando pela união com um homem mortal, Suleyman replica "A submissão ao Islã requer que você não proíba o que Deus declarou como permissivel". Ele lhe arruma um casamento com um governante dos jinni, Tubba, o Ancião. Eles retornam ao lêmen. Suleyman faz o rei dos jinni submeter-se à autoridade do novo rei do Iêmen. Com a morte de Suleyman, os jinni são libertados, o reino de Bilqis e Tubba chega ao fim e a narrativa se encerra.

Em primeiro lugar, é preciso citar o contexto político da Arábia que empresta sua contingência à história alcorânica de Bilqis. Para os habitantes da Arábia central, a nobreza real estava vinculada à coragem e intrepidez militar do sistema tribal, de forma que seria inconcebível a um líder político pedir conselhos quanto a questões militares como faz a rainha, desqualificando a autoridade de Bilqis como chefe política. A atenção é focada sobre si no Alcorão por uma razão direta: ela é uma descrente, como várias chefes tribais e donas de caravana contemporâneas ao Profeta. Esses versos aparecem em um momento histórico no qual era necessária a vitória na batalha contra os politeístas, e as conversões eram uma questão de suma importância, envolvendo a necessidade de diplomacia amparada por tecnologias de violência - conversões forçadas, estupros, desapropriação de nichos sagrados de clãs na Caaba, etc. ${ }^{35}$ Cabe, assim, destacar a relação conflituosa entre princípios da fé muçulmana e papéis sociais de gênero, construtos de feminilidade/masculinidade e conversão religiosa nas alegorias em torno de Bilqis.

O Deus monoteísta venerado por muçulmanos representa uma realidade incognoscível que transcende a experiência humana e que só pode ser observável através de Sua criação.

${ }^{35}$ Ver as biografias de Maomé traduzidas no Brasil que tratam desse período de transição de difícil reconstrução, devido à destruição das fontes escritas na tomada da Caaba pelo exército do Profeta (Armstrong, 2002 e Rogerson, 2004). As fontes hindus contradizem as versões islâmicas, por exemplo, Goel (1993) e Oak (2004). 
Seduções e traições de gênero no Islã

Embora Adão, Eva e todas as criaturas tenham reconhecido a eficácia de um Deus verdadeiro, os jinni que desceram à Terra escolheram a desobediência a Ele, o que suscitou a "queda" de Adão e Eva para o politeísmo. Bilqis/jinni teria se equivocado em dois sentidos: como soberana do Iêmen, teria usurpado o lugar "natural" do homem, para, em seguida, conduzir o povo ao culto politeísta ao sol, surrupiando o reconhecimento dos humanos a Deus. Porém, na tradição islâmica, os ardis de Bilqis não superam a sabedoria de Suleyman; as regras de gênero são claras:

(....) disguised appearences cannot hide what nature has decreed even in childhood before the sexes are more prominently differentiated by hairiness, voice, physical stature and the like. Once again Solomon read cultural (or natural) codes with consummated accuracy. In God's design, aggressiveness and power are reserved for the male species. No doubt, the Queen of Sheba is a most impressive woman but she cannot master the most impressive of men. In any case, that is the conventional wisdom of this tradition and all the others previously cited (Lassner, 2002:149). ${ }^{36}$

Para Lassner, os artefatos culturais judaicos teriam sido utilizados, no limite, para legitimar a mensagem profética de Maomé, sendo uma espécie de conforto para judeus recémconvertidos na Arábia devido às políticas repressivas. Maomé traça sua origem profética pela genealogia de Noé, Moisés e todos os profetas israelitas representantes de uma tradição monoteísta, amparada no discurso de um passado religioso sólido, borrando

36 (...) Aparências disfarçadas não podem esconder o que a natureza decretou, mesmo na infância, antes de os sexos serem proeminentemente diferenciados pelos pêlos, voz, estatura física e os traços. Mais uma vez, Salomão leu códigos culturais (ou naturais) com precisão perfeita. Nos desígnios de Deus, agressividade e poder estão reservados à espécie masculina. Sem dúvida, a Rainha de Sabá é uma mulher impressionante, mas ela não pode subjugar o mais impressionante dos homens. De qualquer forma, essa é a sabedoria convencional de tal tradição e de todas as anteriores previamente citadas. 
identidades e alteridades por razões estratégicas. A tradição local teria adaptado certas narrativas para deixá-la inteligível às tribos beduínas em particular, refletindo valores e experiências contemporâneos, tornando-se uma "nova tradição". O objetivo de Maomé e dos califas sucessores era transmitir partes da tradição judaica com a condição de que os fiéis não se desviassem do Islamismo. Por exemplo, a origem genealógica de Bilqis, que assume o tom folclórico da posterior As Mil e Uma Noites ${ }^{37}$, aliado a uma série de outros eventos que são atribuídos ao mundo islâmico.

$\mathrm{Na}$ interpretação do autor, a subversão de Bilqis se revela em vários momentos da saga salomônica islamizada. Inicialmente, ela mesma propõe a aliança com o rei tirano, sem intermediários, quando os casamentos em sua maioria eram sempre arranjados ${ }^{38}$;

${ }^{37}$ O Livro das Mil e Uma Noites é uma coletânea de fábulas que tematizam os mais diversos assuntos da condição humana - amor, o ódio, a compaixão, etc. -, produto de manuscritos incompletos e compilações tardias. Supõe-se que o livro derive de uma matriz iraquiana produzida originalmente em Bagdá, remontando à segunda metade do século XIII e à primeira do século XIV, quando o Império Mameluco estendia-se da Síria até o Egito. Livro das Mil e Uma Noites - ramo sírio - volume I, traduzido do árabe por Mamede Mustafa Jarouche (2005), especificamente a nota editorial.

${ }^{38}$ Mariya, uma cristã copta da época de Maomé, ficou notória pela mesma iniciativa: "This woman had offered herself in marriage [grifo meu] to the Prophet himself, and it is said that she was not the only one to do so. This is proof of the magnetism Muhammed must have had for those around him. It is also evidence of a self-confidence on the part of women in Ancient Arabia totally lacking ... among Muslim women of later centuries [grifo meu]. There are reports of other women who were married to Muhammed but who, when he came to them in the bridal chamber, said: 'I take refuge from you in God.' At this, so it goes, he had them sent back to their families without delay. This, too, shows Arab women at the time of Muhammed were assertive enough to make no secret of their desires or desinclination" [Essa mulher ofereceu sua mão ao Profeta, e diz-se que ela não foi a única a fazê-lo. Isso prova o magnetismo de Maomé. É também prova da auto-confiança das mulheres da Antiga Arábia, algo que lhes falta enquanto muçulmanas séculos mais tarde. Esses são apenas alguns registros de mulheres que foram casadas com Maomé, mas quando este aproximou-se delas na câmara nupcial, ele disse: "Acho refúgio de você em Deus". E eventualmente, ele as 
Seduções e traições de gênero no Islã

mas o reizinho tirano e luxuriento não vive para conquistá-la nem na cama, nem na sala do trono. O regicídio na concepção muçulmana medieval não era algo facilmente defensável $e$ causava estupor coletivo. Lassner faz uma interpretação freudiana dessa passagem, sugerindo que sua cabeça simbolizaria também a castração de seus genitais super-ativos. Embora dona de grande beleza, Bilqis rejeita o estado "natural" do casamento e a obediência a um homem. Como descendente de uma jinni $e$ usurpadora do trono, ela também falha em prestar obediência a Deus, utilizando-se sempre de ardis não muito honestos, entre eles manipular os homens, mandando-lhe presentes e lançando-lhe charadas. Diz Thalabi: "She has already trained (sasat) the leading men to conform [to her wishes] and was experienced at....... manipulating authority" (apud Lassner, 2002:79). ${ }^{39}$ A palavra árabe sasa, usada para seu ato de manipulação de homens, é relevante, pois o verbo siyasah significa "política" no senso comum de administração e é usado também para o treinamento de cavalos $e$ a domesticação de animais. Por fim, a subversão atinge seu ápice na ruptura final do universo: a rainha de Sabá confunde os gêneros através de suas servas e cortesãos; embaralha, portanto, a ordem divina. Se Suleyman falhasse em distinguir os homens das mulheres, isso significaria a tolice de se defender uma "ordem natural", que é tão passível de ser manipulada e confundida (como de fato o é).

Suleyman, ao livrar-se da armadilha, demonstra que homens e mulheres exercem papéis inexoráveis e distintos no mundo ordenado de Deus. Papéis de gênero não podem ser usurpados dentro do que decretou o Onisciente, afinal, ela não é tão sábia assim, pois falha no teste em distinguir a diferença entre o espelho e a água, a ilusão narcísica da identidade/autoridade

mandou de volta para suas famílias sem demora]" (ver o site Sexual Paradox: Islam, Jihad and Sakina. In: Genesis of Eden Diversity Encyclopedia, www.dhusara.com/book/zulu/zulu.htm.

${ }^{39}$ Ela já tinha treinado os governantes homens a se moldarem [a seus desejos] e era experiente em manipular a autoridade. 
que jamais pudera sustentar. A meu ver, aqui ainda nos encontramos atrelados aos fundamentos judaicos de dominação hegemônica presa ao binário ativo/passivo. A seguir proponho uma interpretação que ressalte as alegorias de conversão $e$ relações intercomunais de gênero e nação, que submergem em meio às trocas endogâmicas de parentesco.

Bilqis é uma mulher diferente das outras, retratada como pertencente a uma linhagem não-humana, daí seu suposto êxito em se tornar rainha. Ela destrona quem seria seu usurpador, casando-se com ele, mas não consumando a relação; é mais uma "Rainha Virgem" semi-humana, quase Deusa. Ao ser espionada pelo pássaro mensageiro de Deus, seu reino é descrito como não tendo "direção" ou "liderança", isto é, ele não está "no caminho certo" e pior, não tem uma líder legítima. Sua soberania é apagada, seu trono/autoridade é surrupiado e camuflado e, ainda assim, ela permanece em uma posição ambígua de não renegar nem reafirmar sua autoridade perante Suleyman. À primeira vista, ela não se sustenta discursivamente e cai no logro do espelho/ água, abrindo mão de sua própria identidade/autoridade $e$ "submetendo-se".

A poupa, pássaro confidente do sábio rei, coloca em seu colo uma carta almiscarada. Na Idade Média, o almíscar era um odor considerado afrodisíaco, pois era extraído da secreção da glândula prepucial de uma espécie de veado originário do Tibet $e$ da Índia, ou seja, vinha do "invólucro" do membro erétil. Suleyman não faz nada menos que uma intimação erótica de conversão e "contato": ele oferece-lhe o falo como o caminho reto a Deus. Bilqis lhe responde no mesmo idioma: mistura os gêneros entre seus escravos para confundi-lo e lhe propõe um enigma impregnado de simbolismos sexuais. Ele é desafiado a elucidar a charada da diferença sexual, depois, a "abrir a caixa" e "perfurar a pérola" $e$, não satisfeita, devolve-lhe o desafio da conversão, provocando-o a "desentortar a concha", a concha "desviada", "ilegítima", pagã, fora de seu devido lugar. "Seduza-me, convertame, conquiste-me se fores capaz..." 
Seduções e traições de gênero no Islã

Contudo, Suleyman é dissuadido de seduzi-la, pois suspeitase que a soberana, embora casta, tenha uma beleza imperfeita de pés de casco e pernas cheias de pêlos, remontando à idéia de demônio/jinni, uma não-muçulmana não-depilada, criatura no limiar, transgressora da domesticidade. Isso faz sentido ao olhar falocêntrico, pois ela é filha de uma entidade não-humana rebelde, fracassando parcialmente no teste da perfeição feminina. Sabemos que a depilação e a circuncisão feminina estão na mesma categoria de harr, ou atos de "purificação" que envolvem a passagem pela dor, necessária antes da consumação do casamento. Ainda impura, Bilqis o desafia mais uma vez, perguntando-lhe sobre uma espécie peculiar de líquido. O que ele lhe responde? "Encha os vasos com o suor de cavalos", outra metáfora do ato sexual: vaso/útero que recebe suor/secreção/ sêmen, água que não vem nem da terra nem do céu, mas de orifícios corporais, as fronteiras entre pureza/perigo e dentro/fora. Bilqis está prestes a ceder à sedução dialógica e à possibilidade do gozo dentro da esfera reprodutiva macho/fêmea, mas ainda guarda uma última charada: ela insiste em saber sobre a natureza de Deus, o criador de toda a lógica dos sexos binários, questionando a legitimidade da própria fé muçulmana.

Entretanto, existem contradições nesse trecho da passagem sobre a conversão "pacífica" da rainha. Uma vez muçulmana, Bilqis retorna ao seu reino sem consumar a aliança com Suleyman e sem entrar para o harém ou o clã dos descendentes de Abraão, reproduzindo a linhagem. O que se vê é uma reafirmação do ideal beduíno de laços endogâmicos e a prática pré-islâmica da matrilocalidade. Casada ou não com Suleyman, ela retorna a Sabá, não acorrentada como prisioneira, mas aparentemente com toda a pompa de seu título. Seu corpo é convertido com a eliminação de caracteres inapropriados para a feminilidade islâmica, mas não se trata de uma conversão completa. Sua corporalidade é transformada, mas sua descendência é priorizada ao fazer a passagem entre-fés. 
Por que ela não ocupa o trono ao lado de Suleyman ou este anexa seu reino? Por que a ela se permite reinar e o monarca se contenta apenas com seu juramento? Teria sido um pudor do cronista ao seguir a lei islâmica na qual um marido não pode se apossar da propriedade da esposa? Nessa época, as fontes escritas eram do domínio apenas de poucos literatos (homens), já que a educação em massa de países árabes tornou-se um fenômeno apenas na década de 1950 do século XX (ver Eickelman, 1995). Thalabi era um erudito, um jurista e leitor do dogma; a interpretação da história de Bilqis foi alvo de seu interesse não apenas literário, mas também canônico, devendo ser registrado obedecendo às expectativas de sua religião e sua cultura sobre representações de gênero e raça. $\mathrm{O}$ que representa essa alegoria de conquista incompleta, se conquistar o corpo é também ter o direito ao território? Se considerarmos a consciência histórica do narrador, talvez seja uma alusão ao colapso dos reinos do sul da Arábia que rondam a formação do Islã e seu poder imperialista posterior. O lêmen era um dos focos de maior resistência à aceitação do Islã e aos califas sucessores de Maomé.

Mas se Bilqis "usurpou" o "lugar natural dos homens", como, então, ela teria permanecido rainha? Em um ponto as narrativas históricas da Antiguidade e Idade Média convergem: a rainha de Sabá não perdeu seu reino e não houve guerra; ela viajou e retornou triunfante, garantindo as rotas disputadas de incenso e mirra produzidos em seu reino e distribuídos nas civilizações vizinhas. No Antigo Testamento, diferentemente do Alcorão, não há alegorias de conversão: ela simplesmente visita Salomão com curiosidade em conhecer o mais sábio dos homens, pronuncia seu respeito e dignidade ao trono de Israel, enche-o de elogios segundo o protocolo da época, ambos trocam presentes suntuosos e ninguém a intima a virar uma israelita. ${ }^{40}$ Isso talvez se explique devido a uma diferença doutrinária, pois os judeus não

${ }^{40}$ Livro dos Reis, 1:10 e Crônicas, 2:9. 
Seduções e traições de gênero no Islã

adotam políticas missionárias de propagação do Judaísmo entre os "gentios" nos mesmos moldes que os cristãos e muçulmanos.

É mais provável, no entanto, que a diferença das versões sagradas se dê por conta de diferentes contingências do momento. Como os muçulmanos encaixariam em seu discurso sobre o poder uma soberana que aparece no Alcorão, mas à sua revelia, líder de um culto politeísta (talvez até uma Suma-sacerdotisa, se ela "impôs" o culto ao sol em seu povo) bem-sucedida em sua missão diplomática, como atestavam as várias fontes historiográficas? A "semi-conversão" de Bilqis, que traz em seu bojo a possibilidade de travestismo - escravos disfarçados de mulher, pernas femininas peludas, a reversão de papéis de gênero -, expõe o engodo do poder islâmico na figura de Suleyman rei/profeta e califa, detentor do poder temporal e sagrado, e o constrangimento frente à possibilidade da autoridade sagrada detida por uma "califa mulher" ou um/a "travesti", o incomensurável à Ummah. A alegoria do encontro entre os dois monarcas suscita a mesma linha de questionamentos de McClintock (1995:20): uma análise sobre as contradições do imperialismo, a relação senhor/escrava/o, sujeira/limpeza e a domesticidade; a capacidade de agency das mulheres muçulmanas e descrentes no Estado islâmico e suas implicações contemporâneas na interação entre o que ela chamaria de "limitação social" e "atuação social".

Inicialmente, Bilqis propõe casamento a um homem jovem e depois da conversão ela é compelida a um casamento arranjado pela intermediação de seu "guardião" Suleyman, que escolhe um marido ancião - não sabemos se com ou sem seu consentimento, já que isso nunca foi relevante para as fontes em questão. Seu clitóris teria sido eliminado junto com os pêlos? Seria esperado que ela fosse circuncidada, primeiro por ter se convertido ao Islã e também para ser sexualmente saciada por um marido bem mais velho. Ainda resta mais uma hipótese sobre a questão, pois fontes citadas anteriormente sugerem que os árabes a praticavam em escravas antes do Islã e depois permanece como meritório às crentes, atestando uma possível reversão da prática e indicando a 
Mariane Venchi

inversão de status social. $\mathrm{O}$ que significa transferir uma prática feita sobre o corpo das escravas para o corpo das crentes, em uma misteriosa "transubstanciação" de categorias?

Em meio a tantas obscuridades e contradições narrativas, a desapropriação fragmentada da corporalidade da rainha pagã (pés, pêlos, tornozelos) sempre posta no jogo dialógico da sedução heterossexual, poderia ser interpretada como uma alegoria que retrata o despojamento (a "depilação") da autoridade de mulheres e territórios, apontando para o campo político sendo negociado ao longo do tempo no Islã: a conversão em troca da sobrevivência daqueles que "desobedecem" e traem a lei - a mulher solteira, chefe-de-estado, o judeu, o estrangeiro, os escravos, os não-circuncidados, em suma, os descrentes. Aqui, descortina-se o apagamento de traços de feminilidade na esfera pública e na construção do Estado-nação muçulmano, mostrando a preocupação das autoridades ao lidarem com a alteridade $e$ as leis de incorporação/conversão dentro de seu próprio campo religioso. Permanece sempre uma idéia espaço-temporal de construção de identidades, da domesticidade e do mercado: Bilqis usurpa o "lugar natural do homem" e renega a ordem cronológica de Adão e Eva e a criação do universo. Suleyman corrige, "desentorta" sua rebeldia (jahiliya, paganismo) ${ }^{41}$ e a resgata novamente para os códigos culturais, a Lei do califado, porém, deixando para trás o rastro do apagamento que a constituiu.

No interstício real/imaginário, Azar Nafisi (2002) discute o eixo principal do Livro das Mil e Uma Noites, a relação entre Sherazade e o sultão Shariar como reflexo de uma possível realidade vivenciada pelas mulheres. Através de seu conhecimento $e$ imaginação, Sherazade dá novos significados e possibilidades a velhos conceitos, uma habilidade que a rígida hierarquia classista e sexista das tradições islâmicas não conseguiu apagar

${ }^{41}$ Os muçulmanos separam a história islâmica em dois períodos cronológicos: antes do advento do Islã, chamado de "era da ignorância" (jahiliyya) x o período da pregação de Maomé marcado por sua fuga de Meca para Medina, a Hégira, a partir da qual se inicia o calendário anual islâmico. 
Seduções e traições de gênero no Islã

completamente. A narrativa seria uma metáfora das esferas públicas $e$ privadas $e$ da interdependência de ambas, simbolizando as relações mais problemáticas da sociedade: a assimetria de poder entre homens $e$ mulheres $e$ alternativas para superá-la. Para a autora, trata-se de um tema atemporal $e$ repetitivo: o que acontece quando a realidade fecha todas as portas, quando a vida parece incontrolável e imutável?

Antes da entrada de Sherazade no romance, as mulheres pertenciam a duas categorias: aquelas que traem $e$ são mortas $e$ aquelas que são mortas antes de terem a chance de trair. $\mathrm{Na}$ história, o sultão Shariar é traído pela esposa com um escravo e, desde então, adquire ódio às mulheres, decidindo matar uma virgem, noite após noite, depois de deflorá-las, até o momento em que a filha do vizir, Sherazade, se compromete a desposar o rei $e$ reverter a situação. ${ }^{42}$ Se no primeiro momento a narrativa fala sobre a humilhação sofrida pelas mulheres - a humilhação da traição sentida pelo rei e a impotência das noivas assassinadas, em uma relação agressor/vítima -, Nafisi situa Sherazade como a única alternativa possível para romper esse círculo de violência. Através do conhecimento, a filha do vizir adota uma posição de mediadora em relação ao sultão $e$ às moças do reino. Conhecendo a história de poetas passados, homens letrados, reis, gênios e magos, a erudição dessa noiva permite que Shariar comece a nutrir uma curiosidade em relação às mulheres, em busca do que ela chama da "pérola oculta da verdade", superando a crença de que todas as mulheres nascem traidoras. Sherazade usa o conhecimento e a imaginação para romper com o ciclo de ressentimentos e matança, entendendo o passado $e$ predizendo o futuro, servindo-se dos contos em seu intento de salvar as outras. Ela arrisca a vida, porém não sucumbe ao medo

${ }^{42}$ Como sabemos, mulheres mortas, seja por membros de suas famílias de origem, seja por seus cônjuges, não são apenas personagens de As Mil e uma Noites. Para uma discussão sobre crimes de honra no contexto islâmico, ver Rouhana, 2006. 
Mariane Venchi

pelo rei e alcança seus objetivos; com sua estratégia de sedução, transforma a realidade.

É possível pensar no papel de Sherazade e da Rainha de Sabá posicionadas como sedutoras a partir de Jean Baudrillard (2006) em relação ao interstício sedução e gozo. O autor contrapõe a Lei - um sistema de valores tomado como universal, a jurisdição o direito, a Socialidade - à Regra, que é imanente à Lei e, contudo, escapa a ela, acarretando a reversão da Lei e estabelecendo uma relação dual entre ambas, Lei e Regra, que ele denomina Ritualidade. A ritualidade engloba os vivos e os mortos, os animais, a natureza, seus processos periódicos, suas recorrências. Tais catástrofes são signos que estabelecem a Regra $e$ seus "jogos de analogia" que organizam o cíclico e a troca universal. A sedução normatiza as aparências, é uma estratégia do ornamento, pois funda a beleza ritual, esotérica, a relação entre gêneros:

(...) Num sistema masculino dominante, em qualquer sistema dominante (que por isso mesmo torna-se masculino), é a feminilidade que encarna a reversibilidade, a possibilidade de jogo e de implicação simbólica. (...) o feminino é não um sexo oposto ao outro, mas o que remete ao sexo de pleno direito $e$ de pleno exercício, ao sexo que detém o monopólio do sexo [grifo meu]: o masculino, a obsessão de alguma outra coisa, de que o sexo é apenas a forma desencantada: a sedução. Esta é um jogo, o sexo é uma função. A sedução é da ordem do ritual, o sexo e o desejo são da ordem do natural. Defrontam-se no feminino e no masculino essas duas formas fundamentais e não alguma diferença biológica ou ingênua rivalidade de poder (Baudrillard, 2006:27).

"Se-ducere", afastar, desviar do caminho, a paixão como um jogo do domínio do signo, o lugar da eficácia simbólica, que o autor empresta de Lévi-Strauss (1996). Por isso, Suleyman desmaia, "perde" a palavra, pois Bilqis faz a pergunta desviante, 
Seduções e traições de gênero no Islã

daí a necessidade da intervenção divina, o apelo ao pré-discursivo que está fora do jogo dialógico e, por isso mesmo, o encerra. Assim se pensa o amor como um desafio, uma aposta, que Sherazade e Bilqis lançam como única forma de sobrevivência, como bem enuncia Baudrillard:

(...) eu me esquivo, tu não me farás gozar, sou eu quem te fará jogar e quem te roubará o gozo (28). [Para depois constatar] No fundo, o poder não existe; nunca existe a unilateralidade de uma relação de forças sobre a qual instaurar-se-ia uma "estrutura" de poder, uma "realidade" do poder e de seu perpétuo movimento. Esse é o sonho do poder tal e qual nos é imposto pela razão. Mas nada se quer assim, tudo busca sua própria morte, inclusive o poder. Ou melhor, tudo quer trocar-se, reverter-se e se eliminar num ciclo. (...) Só isso seduz profundamente (Baudrillard, 2006:56).

A sedução escapa à representação, à enunciação, pois nos desvia da verdade, destrói contratos sociais e religiosos e funda um pacto, o pacto entre Bilqis e Suleyman ou entre Sherazade e Shariar. Diria Sherazade/Bilqis "O que eu quero não é te amar, te querer, nem mesmo te agradar: é te seduzir - e não importa que me agrades, mas que sejas seduzido", transferindo a citação do filósofo para os lábios de nossa personagem. (Id. ib.:98). Para Baudrillard, a mulher é a fundadora das relações fundamentais da troca, tornando o desafio da sedução "triunfante" e o masculino "residual": um sultão domesticado e acalmado em seu leito nupcial, um rei seguro com a "conversão" de sua rival política pelo corpo/território. Temos então relações de poder que são erotizadas em um drama de servidão e subversão e disputas de identidades de gênero em negociação no campo político de revolução, repressão e contato/conversão. São relações dialógicas que nos fornecem um segundo plano de estratégias sistemáticas de apagamento, fazendo-nos esquecer que as árabes teriam ocupado algum dia alguma posição de poder público - Bilqis o 
Mariane Venchi

fez, mas enquanto usurpadora e de origens sobrenaturais, em última instância, revertida a uma fantasia das intermináveis "noites árabes".

Finalmente, vale dizer que as representações sobre rainhas do Oriente Médio, pensadas na Idade Média, passam pelo crivo da classe: foram produzidas por elites urbanas. Lassner observa que comunidades rurais árabes teriam sido afetadas de maneiras muito diversas pela centralização do poder a partir do surgimento do Islamismo - estatização do governo, militarização do Estado, uma religião oficializada, registrada e controlada pelas mãos de homens, com a subsequente cristalização de papéis femininos mais rígidos e a deterioração de sua posição nas políticas públicas. O corpo da mulher-chefe-de-Estado permanece como um lugar ambivalente, poderoso por sua sexualidade livre $e$ intocada, porém "destronada" pela Lei do escrutínio, através da qual a dualidade, jahiliyya, o politeísmo, o anti-édipo são convertidos à unilateralidade assimétrica, à submissão/islâm, à sedução interrompida pela temporalidade de Alá.

\section{Referências bibliográficas}

ABU-SAHLIEH, Sami. Male \& Female Circumcision Among Jews, Christians and Muslims - religious, medical, social and legal debate. Pennsylvania, Shangrila Publications, 2001.

Al-SaADAWI, Nawal. The Hidden Face of Eve - Women in the Arab World. London, Zed Books, 1991.

ARMStrong, Karen. Maomé - Uma biografia do Profeta. São Paulo, Companhia das Letras, 2002.

BARTHES, Roland. Fragmentos de um discurso amoroso. São Paulo, Martins Fontes, 2003.

BAUdRILlard, Jean. Da Sedução. Campinas, Papirus, 2006.

BEACH, Eleanor Ferris. The Jezebel Letters - religion and politics in ninth-century Israel. Minneanapolis, Fortress Press, 2005.

BEGG, Ean. The influence of the East. In: The Cult of the Black Virgin. London, Penguin Books, 1996. 
Seduções e traições de gênero no Islã

BODDY, Janice. Wombs and Alien Spirits - women, men and the Zar cult in Northern Sudan. Madison, University of Wisconsin Press, 1989.

BUTLER, Judith. Fundamentos contingentes: o feminismo e a questão do pós-modernismo. Cadernos Pagu (11), Campinas-SP, Núcleo de Estudos de Gênero - Pagu/Unicamp, 1998, pp.11-42.

DOUGLAS, Mary. Introdução e Fronteiras exteriores. In: Pureza e Perigo Ensaio sobre as noções de poluição e tabu. Lisboa, Edições 70, 1976.

EICKELMAN, Dale F. Mass higher education and the religious imagination in contemporary Arab societies. In: The Book in The Islamic World The written word and communication in the Middle East. New York, The Library of Congress, 1995.

GoEL, Sita Ram. Islamic theology of iconoclasm. In: Hindu Temples: what happened to them - the Islamic evidence, volume II. New Delhi, Voice of India, 1993.

. Was the Ka'ba a Siva Temple? In: Hindu Temples: what happened to them - the Islamic evidence, volume II. New Delhi, Voice of India, 1993.

GOMES, Purificacion Barcia. Sheerazade feminista? In: $O$ método terapêutico de Sheerazade: Mil e uma histórias de loucura, desejo e cura. São Paulo, Iluminuras, 2000.

HOURANI, Albert. O pensamento árabe na era liberal - 1798 - 1839. São Paulo, Companhia das Letras, 2005.

JAROUCHE, Mamede Mustafá. Livro das Mil e Uma Noites - ramo sírio volume I. São Paulo, Globo, 2005.

KENNEDY, John G. Circumcision and excision in Egyptian Nubia. Man The journal of the Royal Anthropological Institute, 5(2), 1970.

LASSNER, Jacob. Demonizing the Queen of Sheba - Boundaries of gender and culture in postbiblical Judaism and medieval Islam. Chicago, The University of Chicago Press, 2002.

LÉVI-STRAUSS, C. A eficácia simbólica. In: Antropologia Estrutural I. Rio de Janeiro, Tempo Brasileiro, 1996.

MCCLINTOCK, Anne. Imperial Leather - Race, Gender and Sexuality in the Colonial Context. NY/London, Routledge, 1995.

MERNISSI, Fátima. The Forgotten Queens of Islam. Minneapolis, University of Minnesota Press, 2003. 
Sonhos de transgressão - minha vida de menina num harém. São Paulo, Companhia das Letras, 1996.

NAFISI, Azar. Imagination as subversion: narrative as a tool of civic awareness. In: Muslim Women and the Politics of Participation. Syracuse/NY, Syracuse University Press, 2002.

OAK, P.N. Was the Kaaba originally a Hindu Temple? 2004. www.hindunet.com/forum/

Rogerson, Barnaby. O Profeta Maomé - uma biografia. Rio de Janeiro, Record, 2004.

ROUHANA, Hoda. Crimes de honra - perspectiva de mulheres que vivem sob lei muçulmana. In: CORRÊA, Mariza e SOUZA, Érica Renata de. Vida em Família - uma perspectiva comparativa sobre "crimes de honra. Campinas-SP, Núcleo de Estudos de Gênero - Pagu/Unicamp, 2006.

SHOHAT, Ella. Des-orientar Cleópatra: um tropo moderno de identidade. Cadernos Pagu (23), Campinas-SP, Núcleo de Estudos de Gênero Pagu/Unicamp, 2004, pp.11-54.

SiCUTERI, Roberto. Lilith - A Lua Negra. São Paulo, Paz e Terra, 1998.

Ud-Din AtTAR, Farid. A Linguagem dos Pássaros, São Paulo, Attar Editorial, 1991.

The Noble Qur'an - English Translation of the meanings and Commentary. Madinah, King Fahd Complex For the Printing of the Holy Qur'an, 2005. 